\title{
Structural and functional characterizations of an Activin type II receptor orthologue from the pacific oyster Crassostrea gigas
}

\author{
Hervé Le Quéré ${ }^{a}$, Amaury Herpin $^{c}$, Arnaud Huvet $^{b}$, Christophe Lelong $^{a}$ and Pascal Favrel ${ }^{a, *}$ \\ a UMR M100 IFREMER - Université de Caen Basse-Normandie « Physiologie et Ecophysiologie des Mollusques \\ Marins », IBFA, IFR 146 ICORE, Esplanade de la Paix, 14032 Caen Cedex, France \\ ${ }^{\mathrm{b}}$ UMR M100 IFREMER - Université de Caen Basse-Normandie « Physiologie et Ecophysiologie des Mollusques \\ Marins », Centre IFREMER, 29280 Plouzané, France \\ ${ }^{c}$ Department of Physiological Chemistry I, University of Würzburg, Am Hubland, 97074 Würzburg, Germany
}

*: Corresponding author : P. Favrel, Tel: +33(0)231565361, Fax: $+33(0) 231565346$, email address : pascal.favrel@unicaen.fr

\begin{abstract}
:
Members of the Transforming Growth factor beta (TGF- $\beta$ ) superfamily of cell signalling polypeptides are known to play important roles in cell proliferation and differentiation during development and in various physiological processes of most animal clades. Recent findings in the mollusc Crassostrea gigas demonstrate the occurrence of a diversity of TGF- $\beta$ signalling components including various ligands, three type I receptors but only a single type II receptor. This report describes the characterization of Cg-ActRII, a new type II receptor displaying homology with vertebrate and Drosophila Activin type II receptors. The use of zebrafish embryo as a reporter organism revealed that, in a way similar to its zebrafish counterpart, overexpression of $\mathrm{Cg}$-ActRII or its dominant negative acting truncated form resulted in a dose dependent range of dorsoventral defects coupled with anterior disorders. Expression pattern of $\mathrm{Cg}$-ActRII transcripts examined by real time PCR and in situ PCR in C. gigas showed high levels of Cg-ActRII transcripts in early embryonic stages and in the developing larval central nervous system. Except for a high expression in the visceral ganglia, most oyster adult tissues displayed rather low levels of transcripts. Altogether, the data suggest a high degree of conservation at both the structural and functional levels during evolution for this class of receptors.
\end{abstract}

Keywords: Mollusc; Lophotrochozoa; Development; Nervous tissues; Activin receptor

Abbreviations: UMR M100, Unité Mixte de Recherches M100; PE2M, Physiologie et Ecophysiologie des Molluques Marins; UCBN, Université de Caen Basse-Normandie.

\section{Introduction}

Molecules of the Transforming growth factor $\beta$ (TGF- $\beta$ ) superfamily regulate various cellular and physiological processes such as cell proliferation, differentiation or early embryonic development (Driever, 1995; Ashcroft, 1999; Herpin et al., 2004; Clarke and Liu, 2008). Members of this superfamily transmit signal through heterodimeric complexes of type I and 
type II serine threonine/kinase receptors (Ten Dijke et al., 1996). Binding of dimeric ligands to two type II receptors leads to the formation of a heterotetracomplex in which two type II receptors transphosphorylate the juxtamembrane GS (Glycine / Serine tandem repeat) domain of two type I receptors. Activated type I receptors in turn phosphorylate specific receptor substrates (SMADs) (Derynck, 1994), organized in multisubunit complexes that move into the nucleus to regulate transcription of target genes (Massague and Wotton, 2000). Based on the class of ligand they bind or transduce, both type II and type I receptors are divided into three main categories: BMP (Bone morphogenetic protein), Activin and TGF- $\beta$ receptors.

Due to the wealth of genetic data available, the components of the TGF- $\beta$ superfamily are well known in the deuterostome and the ecdysozoan clades. In contrast, information is less consistent in lophotrochozoans, the third clade of bilaterian animals (Adoutte et al., 2000). However in this later clade, an extensive study in the oyster Crassostrea gigas has led to the characterization of most categories of ligands, BMP-like ligands (Lelong et al., 2000; Herpin et al., 2004; Fleury et al., 2008), TGF- $\beta$-related ligands (Lelong et al., 2007) and Activins (unpublished results) involved in physiological processes similar to those of their vertebrate and ecdysozoan counterparts. To signal such a diversity of ligands, in Lophotrochozoans three type I receptors of each category have been identified (Herpin et al., 2002; Herpin et al., 2005a; Herpin et al., 2005b) but only a single BMP type II receptor. This later receptor however displays a quite exotic structure with two extracellular domains having the ability to interfere independently with BMP and activin ligand induced pathways respectively (Herpin et al., 2005a). Thus the possibility was suggested that this unique pleiotropic and promiscuous type II receptor constitutes a shared interface for both BMP and activin pathways. Nevertheless, in line with the situation met in deuterostomes and ecdysozoans, additional type II receptors might be required for fine-tuning the biological responses of the target cells to an already significant repertoire of ligands characterized in oyster. 
In this paper we have identified of a new Activin type II receptor from the oyster Crassostrea gigas and have investigated its expression pattern in adult tissues and in developmental stages. To overcome technical limitations relative to our model for assessing its functionality, we have examined the ability of this receptor to interfere with the zebrafish TGF- $\beta$ pathway by injecting oyster wild type or truncated receptors in zebrafish embryos.

\section{Materials and methods}

\subsection{Animals}

Adult oysters Crassostrea gigas were purchased from a local oyster farm (Normandie, France). For analysis of gene expression in adult tissues, mantle, mantle edge, gills, digestive gland, quick muscle of the Posterior Adductor Muscle (PAM), catch muscle of the PAM, atrium (heart), ventricle (heart), haemocytes, labial palps, visceral ganglia were dissected from these oysters and pools of 6 oysters ( 4 pools for each tissue) were prepared for total RNA extraction. For gonad, reproductive stage and sex were histologically determined: stage 0 (sexual resting stage), male and female stage I (gonial multiplication stage), male and female stage II (tubule development and maturation stage) and male and female stage III (sexual maturity) (Rodet et al., 2005). Embryos and larval stages were produced at the IFREMER shellfish laboratory of Argenton (France) following the procedure described in (Fabioux et al., 2004).

\subsection{Cloning of an Activin type II receptor cDNA from C. gigas}

A full-length sequence of $C g$-Act RII was obtained by extending a single EST of 1319 bp (AM855334) of Crassostrea gigas obtained in the frame of a "Marine Genomics Europe" program (Tanguy et al., 2008). This extension was realized by 5'- and 3'-RACE using 
Marathon cDNA amplification kit (Clontech). Doubled stranded cDNA from oyster mantle edge was ligated to adaptors and $25 \mathrm{ng}$ of this template was used to PCR amplify 5'- and 3'RACE fragments using adaptor specific primers and gene specific primers deduced from the initial 826 bp EST. Recovered fragments were gel-extracted (QIAquick ${ }^{\circledR}$ Gel Extraction Kit, Qiagen), sub-cloned with a TOPO-TA cloning ${ }^{\circledR}$ kit (Invitrogen) and then sequenced. To check the actual contiguity of 3 ' and 5' RACE fragments and to generate a single fragment, PCR was then performed with most $5^{\prime}$ and $3^{\prime}$ specific primers using the proofreading DNA polymerase $P f u$ (Promega) and the recovered fragment was sequenced again.

\subsection{Phylogenetic analysis}

For phylogenetic analyses, TGF- $\beta$ superfamily receptor protein sequences were chosen to represent a range of type I and type II superfamily members from each main clades of bilaterian animals. The sequences were aligned using Clustal W (Thompson et al., 1994) and by manual inspection. From these alignments, distance based phylogenetic trees were constructed using the neighbour joining method of the Phylip package with one thousand bootstrap trials for each node.

\subsection{Real time RT-PCR}

Real time RT-PCR analysis was performed using the iCycler iQC apparatus (Bio-Rad). Total RNA was isolated from embryos, larvae and adult tissues using Tri-Reagent (Sigma-Aldrich) according to the manufacturer's instructions. Recovered RNA was then further purified on Nucleospin RNAII columns (Macherey-Nagel). After treatment during $20 \mathrm{~min}$. at $37^{\circ} \mathrm{C}$ with

$1 \mathrm{U}$ of DNase I (Sigma) to prevent genomic DNA contamination, $1 \mu \mathrm{g}$ of total RNA was reverse transcribed using $1 \mu \mathrm{g}$ of random hexanucleotidic primers (Promega), $0.5 \mathrm{mM}$ dNTPs and 200U MMuLV Reverse Transcriptase (Promega) at $37^{\circ} \mathrm{C}$ for 1 hour in the appropriate 
buffer. The reaction was stopped by incubation at $70^{\circ} \mathrm{C}$ for $10 \mathrm{~min}$. $\mathrm{iQ}^{\mathrm{TM}} \mathrm{SYBR}$ Green supermix PCR kit (Biorad) was used for real time monitoring of amplification (5 ng of cDNA template, 40 cycles: $95^{\circ} \mathrm{C} / 15 \mathrm{~s}, 60^{\circ} \mathrm{C} / 15 \mathrm{~s}$ ) with the following primers: Qs-Cg ActRII 5'CACTGGAGGACATGCAAGAA-3' and 2'GGCTGCAACCTGCTCTAAAC-3'as sense and antisense primers respectively. Accurate amplification of the target amplicon was checked by performing a melting curve. Using QsCg-EF (5'-5'-ACCACCCTGGTGAGATCAAG-3') and Qa-CgEF (5'ACGACGATCGCATTTCTCTT-3') primers, a parallel amplification of oyster Elongation Factor $\alpha(\mathrm{EF} \alpha)$ transcript (BAD15289) was carried out to normalize the expression data of $C g$-ActRII transcript. The relative level of $C g$-AcRII expression was calculated for one copy of the reference elongation factor $\alpha$ gene by using the following formula: $\mathrm{N}=2^{(\mathrm{Ct} \mathrm{EF} \alpha-\mathrm{Ct} \mathrm{Cg} \text { - }}$ ActRII)

\subsection{Zebrafish maintenance and preparation of eggs}

$\mathrm{TAB}$ zebrafish were raised and maintained on a light/dark cycle essentially as described by Westerfield (Westerfield, 1989). Synchronised eggs were obtained by mixing previously separated female and male fish at a ratio of 2:1. Eggs were then collected as described by Culp et al. (1991). Self-digested Pronase E (Sigma) at $0.5 \mathrm{mg} / \mathrm{mL}$ was used to remove the egg chorion. The reaction was stopped by removing the enzyme and then transferring the eggs into Holtfreter's solution ( $85 \mathrm{mM} \mathrm{NaCl}, 1 \mathrm{mM} \mathrm{KCl}, 1 \mathrm{mM} \mathrm{CaCl} 2$ and $3.5 \mathrm{mM} \mathrm{NaHCO} 3)$ and rinsing.

\subsection{Microinjections}

Initially, a full length cDNA encoding $C g$-ActRII was subcloned into the plasmid pRN3 (Lemaire et al., 1995). Dominant-negative controls of $C g$-ActRII were obtained by inserting a stop codon downstream of the sequence encoding the transmembrane domain. Capped 
synthetic mRNA encoding both full length and truncated proteins were transcribed in vitro with T3 RNA polymerase and the Ambion RNA capping kit using KpnI linearized plasmids as templates. Capped mRNAs were dissolved in RNAse-free $0.2 \mathrm{M} \mathrm{KCl}$ containing $0.5 \%$ phenol red for injection. The mRNA solution was injected into the cytoplasm of single-cell embryos. After injection, embryos were transferred into 24-well tissue culture plates containing Holtfreter's solution (5-7 embryos per well) and incubated at $28^{\circ} \mathrm{C}$ for $24-30$ hours then examined by microscopy for phenotype analysis. Unfertilised eggs were removed after 4 hours. Alternatively, embryos were fixed for in situ hybridization at $80 \%$ epiboly. Uninjected and control embryos injected with $0.2 \mathrm{M} \mathrm{KCl}$ containing $0.5 \%$ phenol red were analyzed under the same conditions. For all in situ hybridizations and phenotype analyses around 50-80 embryos were analyzed for each concentration of mRNA injected.

\subsection{Whole-mount in situ hybridizations}

Anti-sense probes were transcribed in vitro and labelled using digoxigenin-labelled UTP (Roche). The anteroaxial goosecoid (gsc) mesodermal marker (Thisse et al., 1994), and the ventrolateral tbx6 mesodermal marker (Hug et al., 1997) were used as probes. Whole-mount staining of embryos was performed as described by Rissi et al. (Rissi et al., 1995).

\subsection{Whole mount in situ RT-PCR on oyster embryos and larvae}

Embryos and larvae were fixed in MEMPFA-T buffer (0.1 MOPS pH 7.4; 2mM EGTA; $1 \mathrm{mM}$ MgSO4; 4\% Paraformaldehyde; 0.1\% Tween 20) at room temperature (RT) at least 1 hour and dehydrated progressively with series of Methanol/MEMPFA mixes (25/75: 50/50; 75/25 and 100/0) 5 min at RT and finally stored at $-20^{\circ} \mathrm{C}$ in methanol. Whole mount in situ RT-PCR was adapted from the protocol described by Pesquet et al. (2004) with minor modifications. Samples were washed $3 \times 10 \mathrm{~min}$ at $4{ }^{\circ} \mathrm{C}$ in $63 \%(\mathrm{v} / \mathrm{v})$ ethanol $/ 2 \%(\mathrm{v} / \mathrm{v})$ acetic acid and 
rinsed in TBS-T under agitation $2 \times 10 \mathrm{~min}$ at $4^{\circ} \mathrm{C}$. Embryos and larvae were treated with proteinase $\mathrm{K}(50 \mathrm{ng} / \mathrm{mL}$ in $\mathrm{TBS}-\mathrm{T})$ at $37^{\circ} \mathrm{C}$ during $20 \mathrm{~min}$ and washed in ultra-pure water $2 \mathrm{x}$ 10 min at RT. The genomic DNA was digested with $10 \mathrm{U}$ of TaqI restriction enzyme in appropriate buffer at $65^{\circ} \mathrm{C}$ during $3 \mathrm{~h}$. Then samples were rinsed $2 \times 10 \mathrm{~min}$ at $\mathrm{RT}$ in ultra pure water. Samples were then incubated in presence of $12 \mu \mathrm{L}$ of water, $1 \mu \mathrm{L}$ of Qa-CgActrII unlabelled gene-specific reverse primer $10 \mu \mathrm{M}$ (described above), heated at $70^{\circ} \mathrm{C} ; 10 \mathrm{~min}$ and placed in ice for 10 min. Reverse transcription (RT) was carried out by adding $6 \mu \mathrm{L}$ of RT mix $(4 \mu \mathrm{L}$ of MMuLV-RT 5x buffer; $2 \mu \mathrm{L}$ of $10 \mathrm{mM}$ of dNTPs solution) and $1 \mu \mathrm{L}$ of MMuLV-RT (200U) to the samples and by incubation at $37^{\circ} \mathrm{C}$ during 1 hour. RT was stopped by a 10 min incubation at $70^{\circ} \mathrm{C}$. RNA hydrolysis was performed by replacing the RT buffer with $0.4 \mathrm{M}$ of $\mathrm{NaOH}$ at $37^{\circ} \mathrm{C}$; 1 hour and washing in $100 \mathrm{mM}$ Tris- $\mathrm{HCl}$ and $150 \mathrm{mM} \mathrm{NaCl} \mathrm{pH}$ $7.5 ; 3 \times 15 \mathrm{~min}$ at RT and finally in ultra pure water $2 \times 15 \mathrm{~min}$ at RT. Amplification was carried out in $8 \mu \mathrm{L}$ of PCR mix ( $2 \mu \mathrm{L}$ of $10 \mathrm{x}$ PCR buffer; $2 \mu \mathrm{L} 25 \mathrm{mM}$ of $\mathrm{MgCl}_{2}$ and $4 \mu \mathrm{L}$ of $200 \mu \mathrm{M}$ of dNTPs); $1 \mu \mathrm{L}$ of $10 \mu \mathrm{M}$ of gene specific reverse primer Qa-CgActRII and $1 \mu \mathrm{L}$ of $10 \mu \mathrm{M}$ of gene-specific fluorescent-labelled forward primer (5, Cy5 TCACTGACCAGATGCCAGTC-3'). Volume was adjusted to $19 \mu \mathrm{L}$ with ultra-pure water and heated at $95^{\circ} \mathrm{C}$ during $2 \mathrm{~min}$. One unit of Taq DNA polymerase (Promega) was added and reaction was performed by 40 cycles of $95^{\circ} \mathrm{C} / 30 \mathrm{sec} ; 53^{\circ} \mathrm{C} / 30 \mathrm{sec} ; 72^{\circ} \mathrm{C} / 40 \mathrm{sec}$ and a final cycle at $72^{\circ} \mathrm{C} / 10 \mathrm{~min}$. Samples were rinsed twice in ultra pure water and mounted on superfrost slides in $80 \%$ glycerol and observed in confocal microscopy

\subsection{Statistical analyses}

A "Chi square" test was used to check the efficacy of $C g$-ActRII or DN-Cg-ActRII mRNA injections in zebrafish embryos and to compare the distribution of the recovered phenotypes at each dose. Multiple comparisons of the relative level of mRNA between tissues, 
reproductive stages and developmental stages were performed using one-way ANOVA followed by a Bonferroni's test

\section{Results and discussion}

\subsection{Cloning of a type II Activin receptor from the lophotrochozoan C. gigas}

A full length 1983 base pair cDNA clone with an open reading frame encoding an inferred 521 amino acid long protein was isolated from $C$. gigas mantle edge (accession number FM253117). The inferred protein sequence demonstrated most resemblance to Activin type II receptors and was thus named $C g$-ActRII (Fig.1). The intracellular region was well conserved and showed about $56.3 \%$ identity (79\% similarity) with human Activin type IIB receptor (Ishikawa et al., 1998), 55.6\% (75\% Similarity) with zebrafish Activin type IIB receptor (Garg et al., 1999) and 50.6\% identity (72\% similarity) with its Drosophila orthologue Punt (Ruberte et al., 1995). In contrast, the extracellular domain displayed a moderate amino acid sequence identity of around 30\% with Drosophila and vertebrate type II Activin receptors but contained 8 predictably spaced cysteine residues, four of which forming a characteristic $\mathrm{CCCX}_{4} \mathrm{C}$ knot near the transmembrane region (Wrana et al., 1994). Despite sequence variability, the conserved spacing of all cysteines probably helps in maintaining a conserved tridimensional structure required for ligand binding. As demonstrated for vertebrate receptors, fine specificity of ligand binding of $C g$-ActRII is probably determined by discreet residues in the extracellular domain but also likely depends of the category of type I receptor with which it interacts (Yamashita et al., 1995). Since Drosophila Punt, with only $20 \%$ sequence identity with its mammalian orthologue, binds human Activin with high affinity and specificity (Childs et al., 1993) we might expect $C g$-ActRII to bind the oyster orthologue of Activin. 
However, the ability of $C g$-ActRII to bind different oyster TGF- $\beta$ superfamily ligands especially in a vivo context cannot be excluded.

\subsection{Cg-ActRII: the missing type II receptor in $\mathrm{C}$. gigas}

A phylogenetic tree was generated using the complete inferred protein sequence of $C g$-ActRII together with members of type I and type II TGF- $\beta$ superfamily receptors from both protostomes and deuterostomes (Fig. 2). The resulting phylogenetic tree revealed two main families: the type I receptor and the type II receptor clusters. Each of these two main clusters was separated into three groups consisting of the canonical trilogy: BMP, Activin and TGF- $\beta$ subfamilies of receptors. Supported by a high bootstrap value (80), $C g$-ActRII indeed clustered within the Activin type II receptor group including human ActRIIB, zebrafish ActRIIB and Drosophila Punt. Interestingly, except for the TGF- $\beta$ specific type II (T $\beta$ RII) receptor which could have been acquired during the gene outbreak that occurred with the emergence of chordates (Herpin et al., 2004), the lophotrochozoan Crassostrea gigas harbours the typical assortment of TGF-beta superfamily receptors with the three family type I receptors and the BMP and Activin type II receptors shared by each bilaterian animal clade.

3.3. Cg-ActRII is functionally active in zebrafish embryos and likely transduces a dorsalizing signal

To determine if $C g$-ActRII was capable of functioning in a way similar to its vertebrate orthologues, capped mRNAs encoding $C g$-ActRII were injected into newly fertilized zebrafish embryos. Specifically, we wished to determine if expression of this molecule was able to perturb the Activin ligand-receptor pathway during embryogenesis. Expression of the full length $C g$-ActRII in this reporter system resulted in a dose dependent range of dorsoventral defects of embryos (Fig. 3A \& B) including uncoordinated embryos for the 
highest doses (Fig 3A: D3 phenotype) and a range of dorsalized embryos caused by medium and low doses of $C g$-ActRII encoding mRNA (Fig 3A: D1-D2 phenotypes). Some embryos showed defects in somite formation (Fig. 3C). Expression of a truncated version of $\mathrm{Cg}$ ActRII, (DN-Cg-ActRII), in agreement with its credible dominant negative activity likely due to its capacity to subtract endogenous ligands, resulted in a concentration dependent increase in the severity of ventralized phenotypes (Fig. 3A \& B). In addition, a noticeable fraction of the DN-Cg-ActRII injected embryos $(10 \%$ for $25 \mathrm{ng} / \mu \mathrm{L})$ displayed fused eyes phenotype (Fig.3C 3-4) coupled with anterior defects. Though these later phenotypes are reminiscent of disruption of Nodal (Aoki et al., 2002; Mathieu et al., 2004) or Activin (Thomsen et al., 1990) signalling, most phenotypes were very similar to those obtained following overexpression of zebrafish activin type IIB receptor (Dr-ActRIIB) (Nagaso et al., 1999) supporting the idea that $\mathrm{Cg}$-ActRII is actually functional in zebrafish in a way similar to its fish orthologue and would mediate the same endogenous ligands as Dr-ActRIIB. To correlate defective gastrulation with these phenotypes, whole mount in situ hybridization of embryos at $80 \%$ epiboly was achieved using two mesodermal markers, the anteroaxial /dorsal gsc mesodermal marker (Thisse et al., 1994) and the tbx6 ventrolateral marker (Hug et al., 1997) (Fig. 3D). Compared to uninjected control embryos, expression of $C g$-ActRII resulted in a consistent expansion in $g s c$ expression at the gastrula stage (Fig. 3D). Additionally dorsal expression of tbx6 was also strongly enhanced and appeared in some cases to cover most of the embryo (Fig. 3D). Accordingly, DN-Cg-ActRII injected embryos exhibited a reduced Tbx6 expression in their dorsal part whereas Gsc was slightly reduced when compared to wild type embryos. Induction of $g s c$ marker was rational with the dorsalized phenotypes recovered and was congruent with previous results obtained either with Dr-ActRIIB or other ectopically expressed oyster TGF- $\beta$ superfamilly components such as the $C g$-TGF- $\beta$ sfRII, an exotic BMP/activin type II receptor harbouring two extracellular binding domains (Herpin et al., 
2005a). With respects to Tbx6 expression, $C g$-ActRII behave to some extent as most oyster ventralizing BMP-like signalling components, the oyster BMP type I receptor $(C g$-BMPR1) (Herpin et al., 2005a) and a Tolloid homologue (Herpin et al., 2007). Hence, increase of the ventrolateral marker Tbx6 expression was surprising in regard to the phenotypes obtained and reminds the induced expression of another ventrolateral marker eve1 upon injection of $\mathrm{Dr}$ ActRIIB (Nagaso et al., 1999). Although firm conclusion would require further investigations looking how specific Smad signalling pathways are modulated, it is already possible to say that $C g$-ActRII like its zebrafish orthologue ( $D r$-ActRIIB) is likely to mediate both Activin and BMP pathways during zebrafish embryogenesis. Dual signalling may rely on the selective use of distinct type I receptors as observed for the Drosophila Activin type II receptor "Punt" which mediates DPP (Decapentaplegic) signalling in combination with the BMP type I receptor Tkv (Thick veins) or the Activin type I receptor Saxophone (Letsou et al., 1995; Ruberte et al., 1995) but achieves Activin-specific signalling with the TGF- $\beta$ type I receptor Baboon (Brummel et al., 1999). Because oyster $C g$-T $\beta R I$ induces a similar pattern as $C g$ ActRII on the expression of the mesodermal markers $g s c$ and $t b x 6$ in zebrafish (Herpin et al., 2005 b), the possibility that $C g$-T $\beta R I$ is one of the receptor partners of $C g$-ActRII can be reasonably anticipated.

\subsection{Cg-ActRII is highly expressed in nervous tissues during development and in adults}

To gain insight into possible physiological roles of $C g$-ActRII, determination of tissue distribution and temporal pattern of expression during development was performed by real time RT-PCR (Fig. 4). Cg-ActRII transcript expression was high in unfertilized oocytes (0.015 copy/copy of $\mathrm{EF} \alpha$ ), significantly dropped during the first embryonic stages (down to 0.001 copy / copy of EF $\alpha$ ) and subsequently raised at the blastula and gastrula stages (up to a mean of 0.03 copy / copy of $E F \alpha$ ), probably as a result of general transcription recovery. Both 
maternal and early embryonic expression might be required for signalling gradients of both BMP and Activin-related ligands known to pattern the body axes in both vertebrates and Drosophila (Frisch and Wright, 1998; Nagaso et al., 1999). In comparison to early embryonic stages, most larval stages of development displayed a rather moderate expression level (around 0.002copy / copy of Elf $\alpha$ ). Whole mount in situ hybridization showed a rather uniform distribution of $C g$-ActRII transcripts in the various embryonic stages tested. For larval stages, especially in the trochophore larvae, three spots of high expression corresponding to the larval nervous ganglia clearly emerged from a faint and uniform signal covering the entire larvae (Fig. 5). Among adult tissues, $C g$-ActRII showed a ubiquitous expression though restrained in intensity except for visceral ganglia whose significant $\mathrm{Cg}$ ActRII expression was above five times the basal level found in other tissues. The spatial and temporal broad and basal level of $C g$-ActRII transcript expression suggests this receptor likely plays multiple roles during development. However, specific focal expression of $\mathrm{Cg}$ ActRII in oyster larval and adult nervous system is evocative of the situation found in Drosophila where an Activin signalling pathway involving Activin-like ligands, the receptors Punt and Baboon, controls axon guidance during embryogenesis (Parker et al., 2006), morphogenesis of adult specific neurons (Zheng et al., 2006) and regulates neuroblast numbers and proliferation rates in the developing larval brain (Zhu et al., 2008). In other respects, the discrete levels of $C g$-ActRII expression in male and female gonads, whatever the sex and the reproductive stage, suggest a possible involvement of an Activin signalling pathway for regulating some aspects of gonad development and reproductive processes in oyster as described in mammals (de Kretser et al., 2002). Another possibility is that $\mathrm{Cg}$ ActRII, in partnership with an oyster type I receptor, mediates og-TGF- $\beta$-like, an oyster gonad-specific transforming growth factor- $\beta$ superfamily member presumed to play a regulatory role in the differentiation and maturation of germ cells (Fleury et al., 2008). 


\section{Conclusions}

1. We report the characterization of $C g$-ActRII, the first activin type II receptor from a Lophotrochozoan.

2. This receptor is actually functional in zebrafish embryos and appears to mediate the same endogenous ligands as its zebrafish orthologue.

3. The pattern of expression of $C g$-ActRII transcripts reveals that this receptor, like its vertebrate and Drosophila counterparts, probably plays a key role in cell fate determination during early development and in larvae and adult nervous system.

4. The data strongly suggest a high degree of conservation at both the structural and functional levels during evolution for this class of receptors

\section{Acknowledgements}

This work was supported by “Conseil Régional de Basse-Normandie”. H. Le Quéré was recipient of a MESR fellowship. A. Herpin was supported by grants from the Deutsche Forschungsgemeinschaft and the European commission. The authors are indebted to MP. Dubos (University of Caen) for technical assistance

\section{References}

Adoutte, A., Balavoine, G., Lartillot, N., Lespinet, O., Prudłhomme, B., de Rosa, R., 2000. The new animal phylogeny: Reliability and implications. Proc. Natl. Acad. Sci. USA 97, 4453-4456.

Aoki, T.O., Mathieu, J., Saint-Etienne, L., Rebagliati, M.R., Peyrieras, N., Rosa, F.M., 2002. Regulation of nodal signalling and mesendoderm formation by TARAM-A, a TGFbeta-related type I receptor. Dev Biol 241, 273-288.

Ashcroft, G.S., 1999. Bidirectional regulation of macrophage function by TGF-beta. Microbes Infect 1, 1275-1282.

Brummel, T., Abdollah, S., Haerry, T.E., Shimell, M.J., Merriam, J., Raftery, L., Wrana, J.L., O' Connor, M.B., 1999. The Drosophila activin receptor baboon signals through dSmad 2 and controls cell proliferation but not patterning during larval development. Genes Dev 13, 98-111. 
Childs, S.R., Wrana, J.L., Arora, K., Attisano, L., O'Connor, M.B., Massague, J., 1993. Identification of a Drosophila activin receptor. Proc Natl Acad Sci U S A 90, 94759479.

Clarke, D.C., Liu, X., 2008. Decoding the quantitative nature of TGF-beta/Smad signaling. Trends Cell Biol 18, 430-442.

Culp, P., Nusslein-Volhard, C., Hopkins, N., 1991. High-frequency germ-line transmission of plasmid DNA sequences injected into fertilized zebrafish eggs. Proc Natl Acad Sci U S A 88, 7953-7957.

de Kretser, D.M., Hedger, M.P., Loveland, K.L., Phillips, D.J., 2002. Inhibins, activins and follistatin in reproduction. Hum Reprod Update 8, 529-541.

Derynck, R., 1994. TGF-beta-receptor-mediated signaling. Trends Biochem Sci 19, 548-553.

Driever, W., 1995. Axis formation in zebrafish. Curr Opin Genet Dev 5, 610-618.

Fabioux, C., Huvet, A., Lelong, C., Robert, R., Pouvreau, S., Daniel, J.Y., Minguant, C., Le Pennec, M., 2004. Oyster vasa-like gene as a marker of the germline cell development in Crassostrea gigas. Biochem Biophys Res Commun 320, 592-598.

Fleury, E., Fabioux, C., Lelong, C., Favrel, P., Huvet, A., 2008. Characterization of a gonadspecific transforming growth factor-beta superfamily member differentially expressed during the reproductive cycle of the oyster Crassostrea gigas. Gene 410, 187-196.

Frisch, A., Wright, C.V., 1998. XBMPRII, a novel Xenopus type II receptor mediating BMP signaling in embryonic tissues. Development 125, 431-442.

Garg, R.R., Bally-Cuif, L., Lee, S.E., Gong, Z., Ni, X., Hew, C.L., Peng, C., 1999. Cloning of zebrafish activin type IIB receptor (ActRIIB) cDNA and mRNA expression of ActRIIB in embryos and adult tissues. Mol Cell Endocrinol 153, 169-181.

Herpin, A., Favrel, P., Cunningham, C., 2002. Gene structure and expression of $C g$-ALR1, a type I activin-like receptor from the bivalve mollusc Crassostrea gigas. Gene 301, 2130.

Herpin, A., Lelong, C., Becker, T., Favrel, P., Cunningham, C., 2007. A tolloid homologue from the Pacific oyster Crassostrea gigas. Gene Expr Patterns 7, 700-708.

Herpin, A., Lelong, C., Becker, T., Rosa, F., Favrel, P., Cunningham, C., 2005a. Structural and functional evidence for a singular repertoire of BMP receptor signal transducing proteins in the lophotrochozoan Crassostrea gigas suggests a shared ancestral BMP/activin pathway. Febs J 272, 3424-3440.

Herpin, A., Lelong, C., Becker, T., Rosa, F.M., Favrel, P., Cunningham, C., 2005b. Structural and functional evidences for a type 1 TGF-beta sensu stricto receptor in the lophotrochozoan Crassostrea gigas suggest conserved molecular mechanisms controlling mesodermal patterning across bilateria. Mech Dev 122, 695-705.

Herpin, A., Lelong, C., Favrel, P., 2004. Transforming growth factor-beta-related proteins: an ancestral and widespread superfamily of cytokines in metazoans. Dev Comp Immunol $28,461-485$.

Hug, B., Walter, V., Grunwald, D.J., 1997. tbx6, a Brachyury-related gene expressed by ventral mesendodermal precursors in the zebrafish embryo. Dev Biol 183, 61-73.

Ishikawa, S., Kai, M., Murata, Y., Tamari, M., Daigo, Y., Murano, T., Ogawa, M., Nakamura, Y., 1998. Genomic organization and mapping of the human activin receptor type IIB (hActR-IIB) gene. J Hum Genet 43, 132-134.

Lelong, C., Badariotti, F., Le Quere, H., Rodet, F., Dubos, M.P., Favrel, P., 2007. Cg-TGFbeta, a TGF-beta/activin homologue in the Pacific Oyster Crassostrea gigas, is involved in immunity against Gram-negative microbial infection. Dev Comp Immunol $31,30-38$. 
Lelong, C., Mathieu, M., Favrel, P., 2000. Structure and expression of mGDF, a new member of the transforming growth factor-beta superfamily in the bivalve mollusc Crassostrea gigas. Eur J Biochem 267, 3986-3993.

Lemaire, P., Garrett, N., Gurdon, J.B., 1995. Expression cloning of Siamois, a Xenopus homeobox gene expressed in dorsal-vegetal cells of blastulae and able to induce a complete secondary axis. Cell 81, 85-94.

Letsou, A., Arora, K., Wrana, J.L., Simin, K., Twombly, V., Jamal, J., Staehling-Hampton, K., Hoffmann, F.M., Gelbart, W.M., Massague, J.et al., 1995. Drosophila Dpp signaling is mediated by the punt gene product: a dual ligand-binding type II receptor of the TGF beta receptor family. Cell 80, 899-908.

Massague, J., Wotton, D., 2000. Transcriptional control by the TGF-beta/Smad signaling system. Embo J. 19, 1745-1754.

Mathieu, J., Griffin, K., Herbomel, P., Dickmeis, T., Strahle, U., Kimelman, D., Rosa, F.M., Peyrieras, N., 2004. Nodal and FGF pathways interact through a positive regulatory loop and synergize to maintain mesodermal cell populations. Development 131, 629641.

Nagaso, H., Suzuki, A., Tada, M., Ueno, N., 1999. Dual specificity of activin type II receptor ActRIIb in dorso-ventral patterning during zebrafish embryogenesis. Dev Growth Differ 41, 119-133.

Parker, L., Ellis, J.E., Nguyen, M.Q., Arora, K., 2006. The divergent TGF-beta ligand Dawdle utilizes an activin pathway to influence axon guidance in Drosophila. Development 133, 4981-4991.

Pesquet, E., Barbier, O., Ranocha, P., Jauneau, A., Goffner, D., 2004. Multiple gene detection by in situ RT-PCR in isolated plant cells and tissues. Plant J 39, 947-959.

Rissi, M., Wittbrodt, J., Delot, E., Naegeli, M., Rosa, F.M., 1995. Zebrafish Radar: a new member of the TGF-beta superfamily defines dorsal regions of the neural plate and the embryonic retina. Mech Dev 49, 223-234.

Rodet, F., Lelong, C., Dubos, M.P., Costil, K., Favrel, P., 2005. Molecular cloning of a molluscan gonadotropin-releasing hormone receptor orthologue specifically expressed in the gonad. Biochim Biophys Acta 1730, 187-195.

Ruberte, E., Marty, T., Nellen, D., Affolter, M., Basler, K., 1995. An absolute requirement for both the type II and type I receptors, punt and thick veins, for dpp signaling in vivo. Cell 80, 889-897.

Tanguy, A., Bierne, N., Saavedra, C., Pina, B., Bachere, E., Kube, M., Bazin, E., Bonhomme, F., Boudry, P., Boulo, V., Boutet, I., Cancela, L., Dossat, C., Favrel, P., Huvet, A., Jarque, S., Jollivet, D., Klages, S., Lapegue, S., Leite, R., Moal, J., Moraga, D., Reinhardt, R., Samain, J.F., Zouros, E., Canario, A., 2008. Increasing genomic information in bivalves through new EST collections in four species: development of new genetic markers for environmental studies and genome evolution. Gene 408, $27-$ 36.

Ten Dijke, P., Miyazono, K., Heldin, C.H., 1996. Signaling via hetero-oligomeric complexes of type I and type II serine/threonine kinase receptors. Curr Opin Cell Biol 8, 139-145.

Thisse, C., Thisse, B., Halpern, M.E.Postlethwait, J.H., 1994. Goosecoid expression in neurectoderm and mesendoderm is disrupted in zebrafish cyclops gastrulas. Dev Biol 164, 420-429.

Thompson, J.D., Higgins, D.G., Gibson, T.J., 1994. CLUSTAL W: improving the sensitivity of progressive multiple sequence alignment through sequence weighting, positionspecific gap penalties and weight matrix choice. Nucleic Acids Res 22, 4673-4680. 
Thomsen, G., Woolf, T., Whitman, M., Sokol, S., Vaughan, J., Vale, W., Melton, D.A., 1990. Activins are expressed early in Xenopus embryogenesis and can induce axial mesoderm and anterior structures. Cell 63, 485-493.

Westerfield, M., 1989. The zebrafish Book. Univ. of Oregon Press, Eugene.

Wrana, J.L., Attisano, L., Wieser, R., Ventura, F., Massague, J., 1994. Mechanism of activation of the TGF-beta receptor. Nature 370, 341-347.

Yamashita, H., ten Dijke, P., Huylebroeck, D., Sampath, T.K., Andries, M., Smith, J.C., Heldin, C.H., Miyazono, K., 1995. Osteogenic protein-1 binds to activin type II receptors and induces certain activin-like effects. J Cell Biol 130, 217-226.

Zheng, X., Zugates, C.T., Lu, Z., Shi, L., Bai, J.M., Lee, T., 2006. Baboon/dSmad2 TGF-beta signaling is required during late larval stage for development of adult-specific neurons. Embo J 25, 615-627.

Zhu, C.C., Boone, J.Q., Jensen, P.A., Hanna, S., Podemski, L., Locke, J., Doe, C.Q., O' Connor, M.B., 2008. Drosophila Activin- and the Activin-like product Dawdle function redundantly to regulate proliferation in the larval brain. Development 135, 513-521.

\section{Figure legends}

Figure 1: Multiple sequence alignment of $C g$-ActRII with members of the Activin receptor type II family using CLUSTAL W. The predicted amino acid sequence of $C g$-ActRII is aligned with the amino acid sequence of two type II Activin Receptors from Homo sapiens (Hs ActRIIB), Danio rerio (Dr-ActRIIB) and Drosophila melanogaster (Dm-Punt). Conserved residues (identity) between the $C g$-ActRII receptor and the three other receptors are shaded in dark grey, light grey shading indicates identity with at least one of the three receptors. Amino acids of the predicted signal peptide are shown in bold letters. Transmembrane domain is underlined. Dashes indicate gaps in the amino acid sequence when compared with other sequences. The black box delimits the potential ATP binding region. Black arrowheads indicate the conserved cysteine residues in the extracellular domain. The dotted line delimits the Serine-Threonine kinase domain. ( $\star$ ) indicates potential N glycosylation sites .

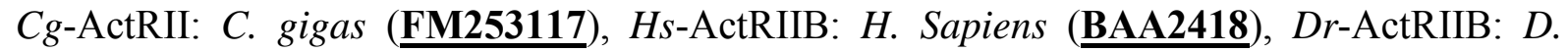

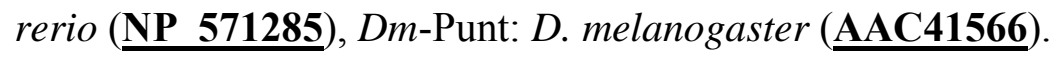


Figure 2: Phylogenetic relationship of TGF- $\beta$ superfamily type I and type II receptors. This tree was generated by using the alignment in CLUSTAL W. From this alignment a distance based phylogenetic tree was constructed using the neighbor joining method of the Phylip package with a validation by bootstrapping method (one thousand bootstrap trials were run)

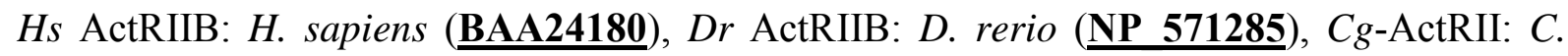

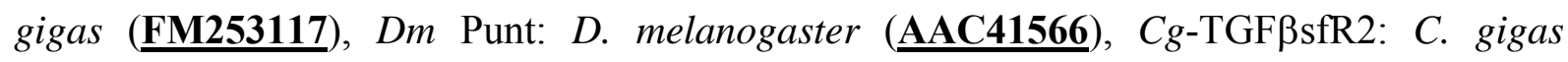
(CAD20574), DmWishful thinking D. melanogaster (囵AF60175), Hs BMPR-II: H. sapiens

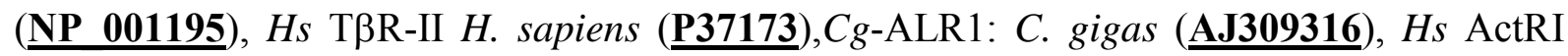

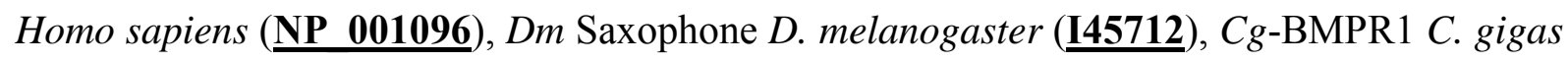
(CAE11917), Hs BMP-RIA: H. sapiens (P 004320), Dm Thick veins: D. melanogaster

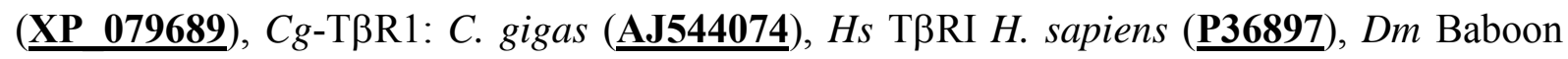

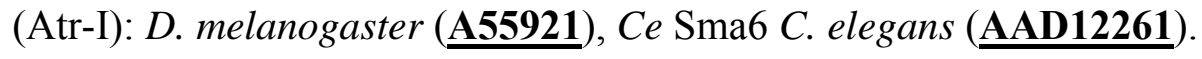

Figure 3: (A) The range of zebrafish phenotypes observed after overexpression of oyster Activin type II receptor ( $C g$-ActRII). Examples showing the dorsalized phenotypes obtained after overexpression of $C g$-ActRII. These phenotypes ranged from the least (D1) to the most severe (D3). Examples showing the ventralized phenotypes obtained after overexpression of truncated DN-Cg-ActRII (dominant negative) lacking the intracellular domain. These phenotypes ranged from the least (V1) to the most severe (V3). (B) Dose-dependent phenotype distribution obtained by overexpression of $C g$-ActRII and truncated $C g$-ActRII (DN-Cg-ActRII). Results are expressed as percent of embryos showing a given phenotype. The number of embryos injected for each concentration of mRNA is indicated in brackets. Paired comparisons of phenotype distributions obtained for each dose of Cg-ActRII mRNA $(a, b, c)$ or DN-Cg-ActRII mRNA $(d, e, f)$ were statistically tracked using $\chi^{2}$ test: Significant differences were observed for $\mathrm{a}, \mathrm{b}, \mathrm{c}\left(\mathrm{P}<10^{-4}\right), \mathrm{d}(\mathrm{P}<0.005)$, e $\left(\mathrm{P}<10^{-4}\right)$ and $\mathrm{f}\left(\mathrm{P}<10^{-3}\right)(\mathrm{C})$ 
Characteristic phenotype of somite development alteration (C1) resulting from overexpression of $C g$-ActRII compared to wild type phenotype (C2) and of fused eyes phenotypes obtained after overexpression of truncated $C g$-ActRII (DN-Cg-ActRII) $(25 \mathrm{ng} / \mu \mathrm{L})(\mathrm{C} 3-4)$. (D) Whole mount in situ hybridization of zebrafish embryos using the dorsal mesoderm marker Goosecoid (Gsc) (D1-3-5) and the ventro-lateral mesoderm marker Tbx6 (D2-4-6). Expression pattern of $g s c$ and $t b x 6$ genes upon injection of $C g$-ActRII and DN-Cg-ActRII $(75 \mathrm{ng} / \mu \mathrm{L})$ at $80 \%$ epiboly.

Figure 4: Distribution of mRNAs encoding $C g$-ActRII during developmental stages, in adult tissues and gametogenesis of Crassostrea gigas measured by real-time quantitative RT-PCR. Each value is the mean $+\mathrm{SE}$ of four pools of 6 animals (adult tissues), or the mean of four pools of embryos or larva from the same spawn (developmental stages), or the mean of four independent animals (gametogenesis). Expression levels are expressed per copy of Elongation Factor $\alpha(E F \alpha)$. Significantly different means $(p<0.01)$ are indicated by letters.

M: Mantle, ME: Mantle edge, G: Gills, DG: Digestive Gland, QM: Quick muscle of the Posterior Adductor Muscle (PAM) CM: Catch Muscle of PAM, A: Atrium (heart) V: Ventricle (heart), H: Haemocytes, LP: Labial Palps, VG: Visceral Ganglia. St0: Stage 0, sexual resting stage, M: Male, F: Female, Stage I: gonial multiplication stage, II: tubule development and maturation stage, IIIA: sexual maturity stage.

Figure 5: In situ distribution of $C g$-ActRII transcripts in oocytes, blastula and trochophore larvae of Crassostrea gigas. In situ RT-PCR was performed with Cy5-labelled forward primer in presence (positive) or absence of Taq DNA polymerase. Controls were also made by missing either TaqI restriction enzyme, RT or by RNA alkali digestion prior to RT-PCR (data not shown). Arrows indicate the nervous ganglia. 
-MFWINIFTSVFFILQHSTGSWSAEAKAAAQ--RRCVVLYP-NCT-ENGGQS-CQRYEYCEPGSHYCFTAWSONNASA --MFASLLTLALLLATFAADPSHGEVET-----RECLYYNV-NWEVEKTNRSGVERCEGEKDKRSHCYASWRNNSGS--MTAPWVALALLWGSLCAGSGRGEAET-----RECIYYNA-NWELERTNOSGLERCEGEQDKRLHCYASWANSSGTMSKYDLLYLTAQLTLVCCLIGIHGS I LPGSHG I IECEHFDEKMCNTTQQCETRIEHCKMEADKFPSCYVLWSVNETTG

NGIELKHQGCWTQNQGCEN-DSCIQSNLQTQSVSFCCCHLDKCNINISMVSIGFSQAVTEKGPTAKVQSDGKAKVMEILMYSLVPIIVLVILIV --IQLVKKGCWLDDFNCYDRQECVATEENPQ-VFFCCCEGNFCNERFTHLPDISGPVIS--PPPVSP------SLLNVLVYSLLPLSMLSMAVI --IELVKKGCWLDDFNCYDRQECVATEENPQ-VYFCCCEGNFCNERFTHLPEAGGPEVTYEPPPTAP------TLLTVLAYSLLPIGGLSLIVL -ILRIKMKGCFTDMHECNQTECVTSAEPRQGNIHFCCCKGSRCNSNQKYIKSTTEATTQVPKEKTQD-----GSNLIYIYIGTSVFSVLMVIVG

IVFVMWRCYYNRNMYTSHLQLPACDPEMGTQEFNQPH PIQLLELRAHGRFGEVWIANMLDAVVAVKIMPFKEKASWLAEOEIYNLPHMKHDNI LAFWMYR---HRKPPYGHVDVNE-DPGPSPPSPLVGL PLQLLEVKARGRFGCVWH AQMINEYVAVKIFPIQDKLSWQNEREMFSTPGMKHDNI LAFWMYR---HRKPPYGHVDI HE-DPGPPPPSPLVGL
PLQLLEIKARGRFGCVWH AQLMNDFVAVKIFPLQDKQSWQSERE IFSTPGMKHENL
MGLLYR----RRKQAHFNEIPTHEAEITNSSPLLSN PIQLLEQKASGRFGDVW AKLNNQDVAVKIFRMQEKESWTTEHDIYKLPRMRHPNI

ITIVGGER--- LRFIAAEKRGSNLEMEFWLITEFHERGSLTDYLKGNAVSWADLCVIAESMACGLAYLHEDVPRSKGEGPKPAIAHRDFKSKNVMLKMDLTAVIG LQF IAAEKRGSNLEVELWLI TAFHDKGSLTDYLKGN I ITWNELCHVAETMSRGLSY LHEDVPWCRGEGHKPS IAHRDFKSKNVLLKSDLTAVLA
LEFLGVEKHMD--KPEYWLISTYQHNGSLCDYLKSHTISWPELCRIAESMANGLAHLHEEI PASKTDGLKPS IAHRDFKSKNVLLKSDLTACIA

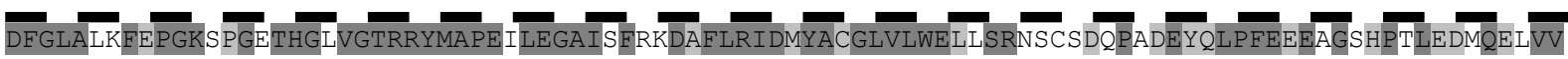
DFGLAVRFEPGKPPGDTHGQVGTRRYMAPEVLEGAINFQRDSFLRIDMYAMGLVLWELVSRCKAADGPVDEYMLPFEEEIGQHPSLEDLQDAVV DFGLAVRFEPGKPPGDTHGQVGTRRYMAPEVLEGAINEQRDAFLRI DMYAMGLVLWELVSRCKAADGPVDEYMLPFEEE IGQHPSLEELQEVV
DFGLAMIFQPGKPCGDTHGQVGTRRYMAPEVLEGA INFNRDAFLRIDVYACGLVLWEMVSRCDFAG-PVGEFOLPFEAFIGLRPSLDEVQESVV

MKKLRPTIIKNHW̄LQFPGIEQVAATIEGCWDQDAEARVSAICVQERLSQISRRTLNVSTSSHNLSISPNQNIYYHISSVSNHKKLRPAFKDCWLKHSGICQMCETMEECWDHDAEARLSAGCVQERISQIRR-VSSSTSDCLFSMVTSLTNVDLPPKESS I HKKMRPTIKDHWLKHPGLAQLCVTIEDCWDHDAEARLSAGCVEERVSLIRRSVNGTTSDCLVSLVTSVTNVDLPPKESS MKKLRPRLINSWRAHPGLNVFCDTMEFCWDHDAFARLSSSCVMERFAQLNK----YPSTQLLIKNHTNIDDAKESTNCI

\section{Fig1}




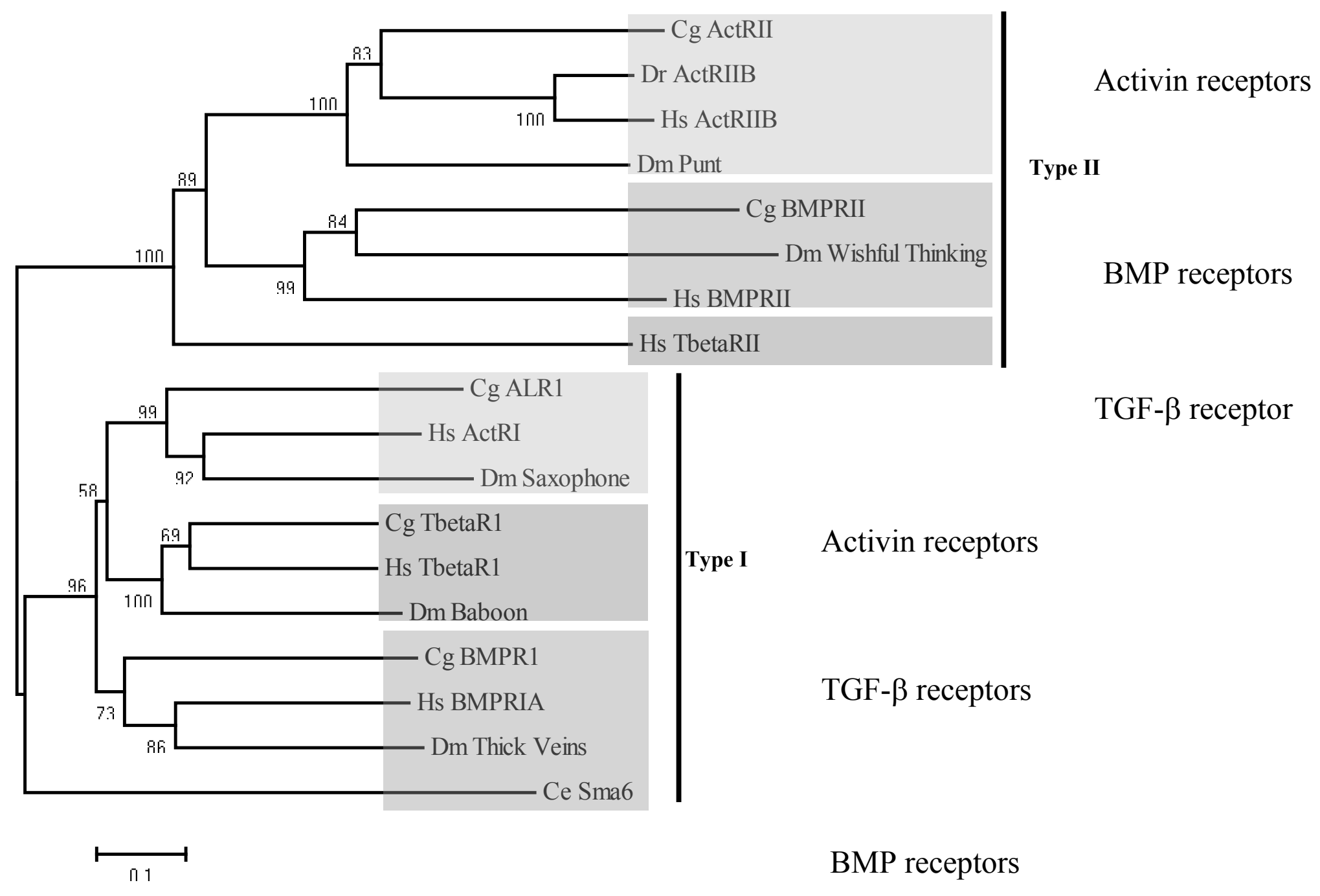

Fig. 2 
A

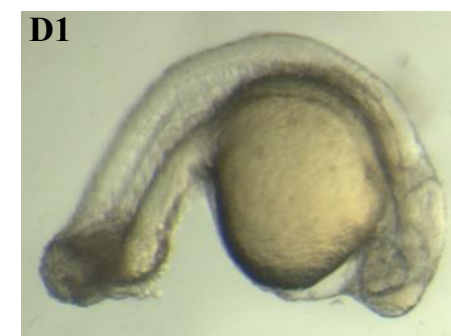

V1

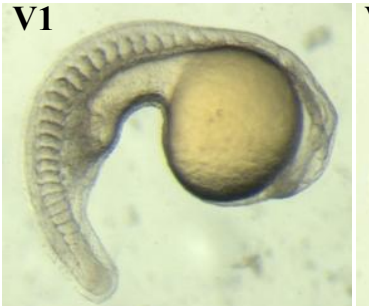

C
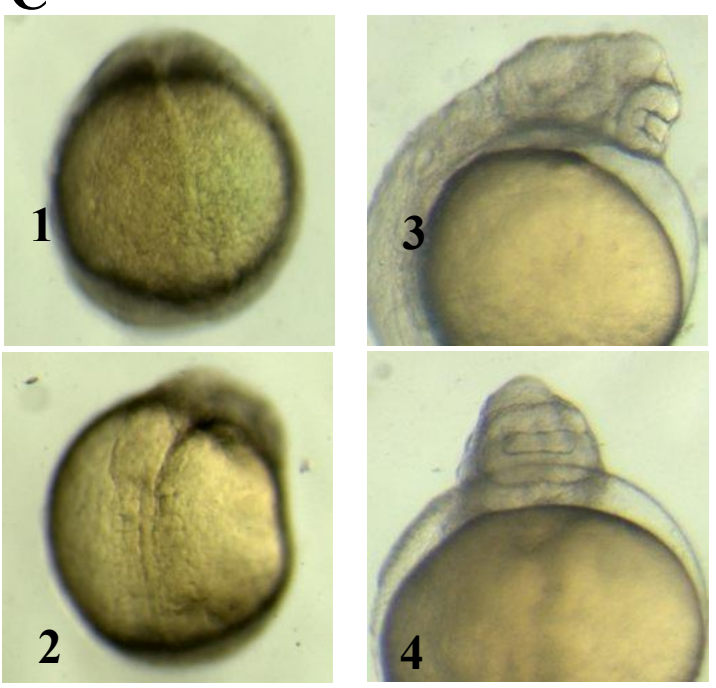

V2
B

Capped RNA

(ng/ $\mu L$ )

Cg-ActRII

25ng/ $\mu \mathrm{L}$

50ng/ $\mu \mathrm{L}$

75ng/ $\mu \mathrm{L}$
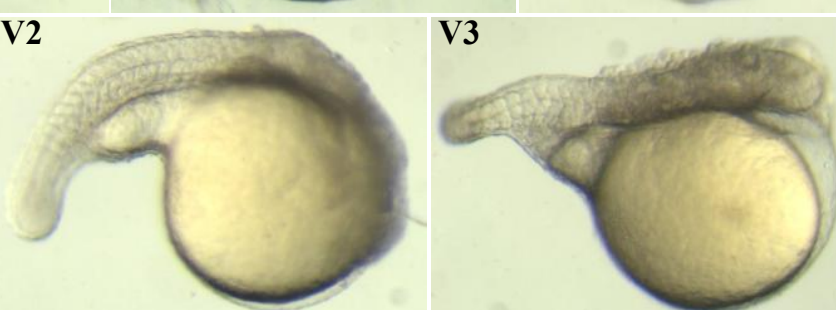

\begin{tabular}{|c|c|c|c|c|c|}
\hline & V1 & V2 & V3 & Normal & $n$ \\
\hline \multicolumn{6}{|c|}{ DN-Cg-ActRII } \\
\hline $25 n g / \mu \mathrm{L}$ & $26(12)$ & $23(11)$ & $17(8)$ & $34(16)$ & 47 \\
\hline $50 \mathrm{ng} / \mu \mathrm{L}$ & $13(7)$ & $30(17)$ & $34(19)$ & $23(13)$ & 56 \\
\hline $75 \mathrm{ng} / \mu \mathrm{L}$ & $4(2)$ & $40(21)$ & $49(26)$ & $7(4)$ & 53 \\
\hline
\end{tabular}

D
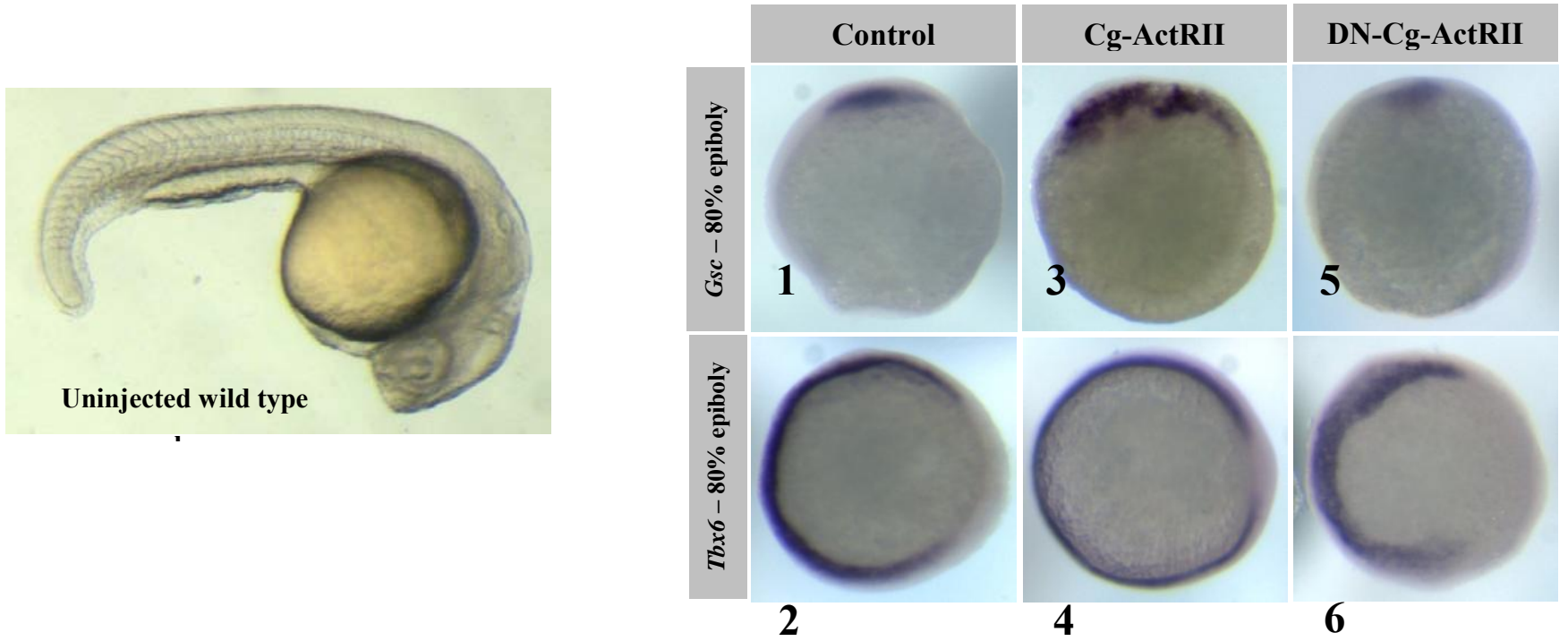

Fig. 3 


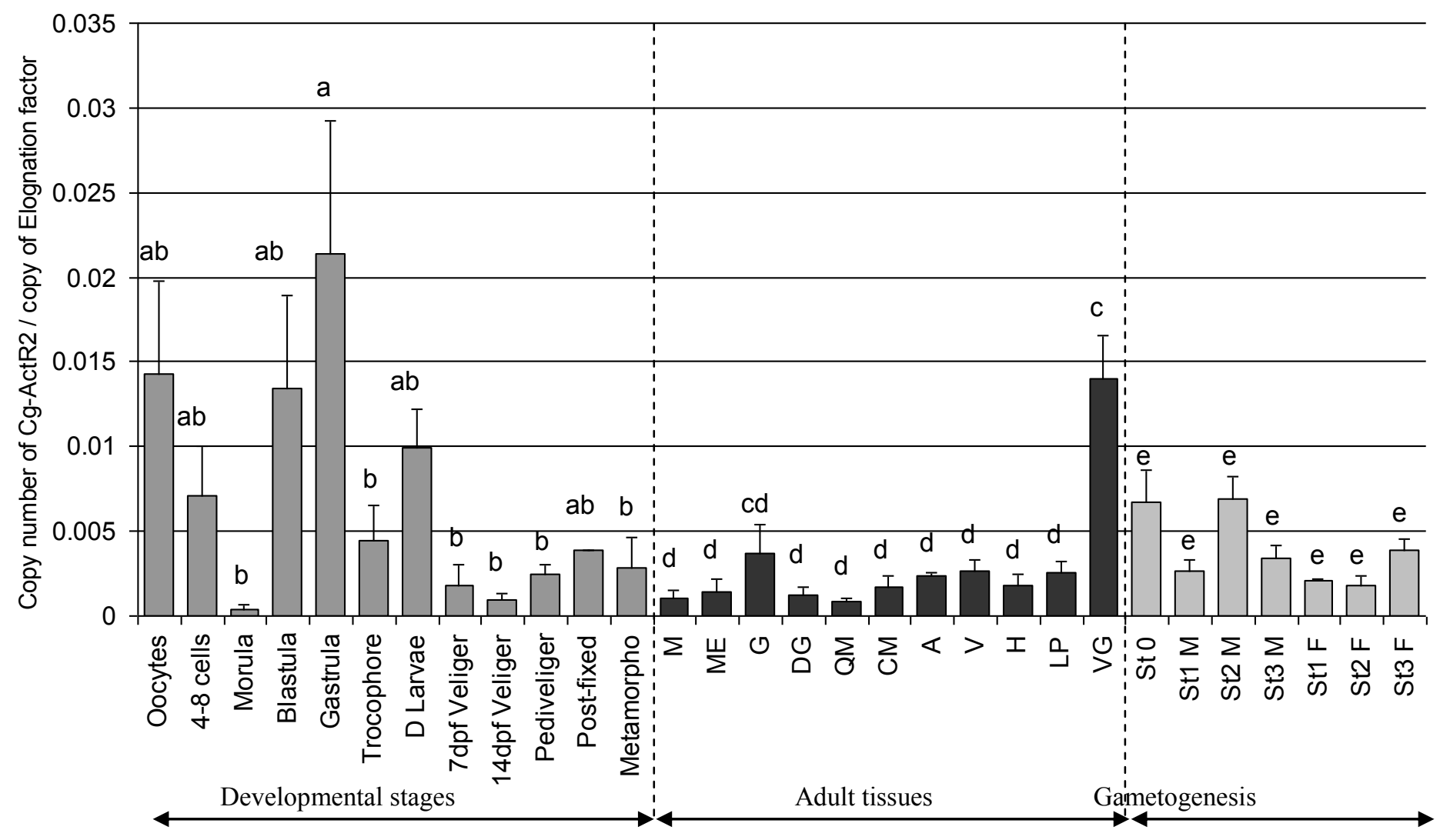

Fig. 4 


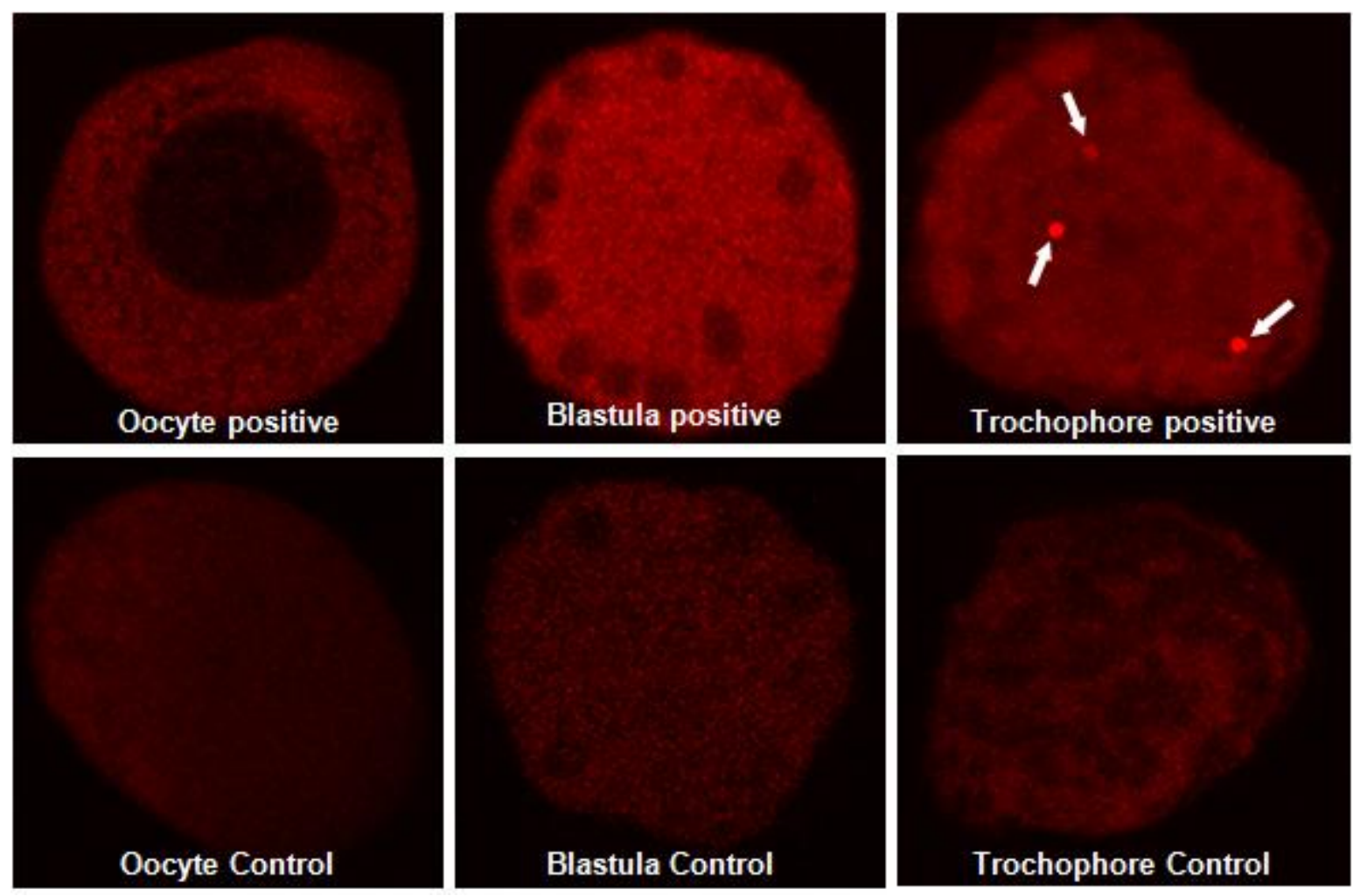

Fig. 5 